Publisher homepage: www.universepg.com, ISSN: 2707-4641 (Online) \& 2707-4633 (Print)

https://doi.org/10.34104/ijma.021.01300136

International Journal of Management and Accounting Journal homepage: www.universepg.com/journal/ijma

\title{
A Comparison of Financial Soundness of Conventional \& Islamic Commercial Banks in Bangladesh: A Bank-O-Meter Model Approach
}

\author{
Shohel Rana ${ }^{1}$ and A.S.M. Kamruzzaman ${ }^{2}$ \\ ${ }^{1}$ Dept. of Finance and Banking, Jatiya Kabi Kazi Nazrul Islam University, Trishal, Mymensingh, Bangladesh \& Ph.D. \\ Fellow, Department of Finance, University of Rajshahi, Rajshahi, Bangladesh, and ${ }^{2}$ Dept. of Finance, University of Rajshahi, \\ Rajshahi, Bangladesh. \\ *Correspondence: s.rana_fb@yahoo.com (Shohel Rana, Associate Professor and PhD Fellow, Dept. of Finance and Banking, \\ Jatiya Kabi Kazi Nazrul Islam University, Trishal, Mymensingh, Bangladesh).
}

\section{ABSTRACT}

The prime objective of the paper is to measure and compare the financial soundness of Conventional as well as Islamic commercial banks in Bangladesh using the Bank-o-meter model. The Bank-o-meter model is the model that helps to find the solvency scores of the banks to avoid insolvency issues and it is used to measure the financial position of banks. This model was developed by International Monetary Fund (IMF). The study found that all the conventional as well as Islamic banks are super sound but Islamic banks are financially less sound compared to their conventional counterparts. The study also suggests that the management of Islamic banks should give extra emphasis on maintaining sound management and ensuring adequate liquidity.

Keywords: Capital adequacy, management efficiency, Earning efficiency, assets quality, and liquidity.

\section{INTRODUCTION:}

Today's business institutions are excessively dependent on banks for funds to sustain and grow. Savings mobilezation, allocation of credit, risk management, reduction of information cost, and the provision of payment services are the main functions performed by financial institutions (Toby, 2006). The banking sector of Bangladesh started its journey after the independence with 6 nationalized commercialized banks, 2 Stateowned specialized banks, and 3 Foreign Banks.

However, after the 1980s with significant access of private banks, now there are 43 private commercial banks including 10 Islamic banks on the principle of interest-free and shariah-based banking business on profit and loss sharing system operating in the country. Alongside Traditional Banks, Islamic Banks have started playing a vital role in contributing to the economy of a country since the 1980s. Islamic banking is based on the Profit Loss Sharing system (PLS) and fixed payments in the name of interest as in conventional or traditional banks are strictly prohibited. This study tries to compare reveal the performance trend of the Conventional and Islami Shariah-based banks in Bangladesh. Today Islamic banking system is the finest alternative to the conventional banking system. The banking principles, rules, regulations, and capital structure of the Islamic banking system are also different from the conventional banking system. Therefore, comparison between two banking systems is essential in view of financial soundness. In other words, the spotlight of this comparative study is to evaluate and measure the statistical differences in the financial performance of the two different banking firm's operating in Bangladesh. For the study, to measure and compare the financial soundness of conventional banks and Islamic banks independent sample t-test and bank-ometer model will be used (Aktar, 2021). 


\section{Review of literatures}

Shar et al. (2010) tried to develop a scale 'bank-ometer' that can better measure the weak point of financial institutions than conventional models, i.e. CAMEL, Credit Leona's Securities Asia stress test (CLSA- stress test), etc. That can ultimately be used to improve the efficiency and soundness of banks operating in Pakistan. The study has focused on the development of bank-o-meter in Pakistan during 1999-2002 and the assessment of the viability of banking institutions. The study also compared the findings of the bank-o-meter with the CAMEL and CLSA- stress test. Capital adequacy, human efficiency, and non-performing loans, etc are examined in detail by applying the bank-o-meter parameter,. This study will help potential investors, account holders, and bank management to make decisions and control the entire financial system to avoid possible future financial crises. This study found that banks that were effective under stress tests but failed to pass the bank-o-meter standard disappeared mainly due to lack of capital. The ratio of capital adequacy of these unincorporated banks was below 4\%. Most of the banks under the CLSA stress test found solvents under the bank-o-meter solvency criteria, while some banks failed the bank-o-meter solvency criteria under the CLSA stress test. Tabash et al. (2017) evaluated the financial performance of Islamic banks and conventional banks operating in the United Arab Emirates. They used a sample of five Islamic banks and fourteen conventional banks performing in UAE over a period of 2011-2014. In their study descriptive analysis, correlation analysis, independent sample t-test, and regression analysis have been used to measure and compare financial performance. They found that there is no sognificant difference of both categories of banks in terms of profitability measured through ROA. Islamic banks have more liquidity and operational efficiency than conventional banks whereas traditional banks are ahead of Islamic banks in capital and risk management. Makkar and Singh, (2012) evaluated solvency levels in commercial banks during the period from 2006-2007 to 2010-2011using bank-o-meter developed on bank ratings under IMF guidelines, as it was thought that the use of traditional therapeutics would be better in implementing CAMEL ratios and CLSA-stress tests. The results of this study explains that the Bank-o-meter model can provide a precise assessment of the perUniversePG I www.universepg.com formance of the bank. Thus, it is advisable for internal management to use the Bank-o-meter model in evaluating the financial performance of banks in India. Rahman, (2017) examined the financial performance of twenty-four private commercial banks conducted in Bangladesh. Instead of using other models, a new effective model called "Bank-o-meter" has been used in this research. This model has been developed to measure the liquidity of banks according to the guidelines of IMF, (2000) and has been used by many researchers for its simplicity. The survey revealed that all the banks have individually secured the financial position and the banking industry has always been in a suitable position during the period (2010-2015). Ultimately, this study concludes that the "bank-o-meter" model will certainly help a bank's internal management in determining the issues of insolvency and overcoming the inadequacy of banking activities (Khalid et al., 2021).

Usman \& Khan, (2012) found that higher growth rates and profits of Islamic banks than conventional banks. Furthermore, Islamic banks also have higher liquidity strength than of their counterpart i.e conventional banks. To create a suitable relative study of Islamic banks (Mezan Bank Limited, Bank Islamic, and Albaraka) and conventional banks (Fasal Bank, KASB, and Bank of Khyber), the sample banks were equal to the invested capital between 2007-2009. To produce significantly more noticeable results, paired-sample Ttests are used. Safiullah, (2010) from his study of 'Superiority of Conventional Banks \& Isla-mic Banks of Bangladesh: A Comparative Study' found that the financial soundness of Islamic banks and con-ventional commercial banks in Bangladesh are appreciable in view of their business developments, liquidity and solvency, profitability, commitment to the economy and community, efficiency and productivity. The study covered 5 years of data from 2004 to 2008 and different financial ratios and statistical tests are used. Conventional banks are doing better than Islamic banks based on the commitment to economy \& com-munity, productivity, and efficiency. Moreover, Islamic banks are superior from the conventional banks in their business development, profitability, liquidity, and sol-vency. Hanif, (2012) analyzed and compared the fina-ncial performance of Islamic as well as conventional banking in Pakistan and also to find out which banking system 
is performing healthier than others are. 22 conventional banks as well as 5 Islamic banks were selected as samples. In order to understand the depth and compare sound, main performance indicators were classified into external and internal banking factors. Analysis of external factor involves understanding customer perceptions and behavior about both types of banking system. Analysis of internal factor measures the difference between the performance of Islamic as well as conventional banks in view of profitability, liquidity, credit risk, and sovereignty. Different financial ratios were used to determine profit, liquidity, and credit risk; and to test solvency bank-o-meter model is used. The findings prove to be in line with the benefits of conventional banking in view of profits and liquidity, while Islamic banking is dominant in credit risk management and maintenance of liquidity. Fayed (2013) used the different financial ratios and Bank-o-meter model to measure and compare the financial performance of Islamic as well as conventional banking in Egypt, and to discover which of the banking streams is perform healthier than the other. For the aim of this study, the researcher took three Islamic banks and six Conventional banks to make comparisons of performance. The finding of this study revealed that Conventional Banks perform healthier than Islamic Banks regarding liquidity, profitability, and credit risk mana-gement as well as solvency.

\section{Objective of the study}

To measure the financial soundness of selected conventional and Islamic commercial banks in Bangladesh. To compare the financial soundness of conventional and Islamic commercial banks in Bangladesh through Bank-o-Meter model. To suggest ways to improve financial status of both categories of banks.

\section{METHODOLOGY:}

\section{Data and Sample}

The study considers the privately owned commercial banks owing of the homogeneity of establishment, rules, regulations, and practices, etc. Sample size is ten of which five are conventional commercial banks and five are Islamic Commercial banks. Secondary data are used in this study. Secondary data are collected from the Audited financial statements i.e. Income Statement and Balance Sheet, Statement of Changes in Owners' Equity, Cash-flow Statement of both Islamic as well as UniversePG I www.universepg.com
Conventional banks for the period of 2010 -2019. The other sources used for data collection are websites and business journals.

\section{Data Analysis}

An Independent Sample t-test is used to determine whether there are any significant differences in the financial soundness of conventional and Islamic commercial banks. To measure and compare the financial performance of both types of banks, the Bank-o-meter model is used.

\section{Parameters used}

Following the suggestions of the International Monetary Fund (IMF, 2000) to deal with the vulnerability of the financial system, it had been thought right to develop a bank-o-meter by employing a minimum number of parameters with the most accuracy in results. This procedure has the standard of least variety of parameters with utmost accurate results.

1. Capital Adequacy Ratio $40 \%=\langle\mathrm{CAR}\rangle=08 \%$

2. Capital to Assets Ratio Capital / Asset $>=04 \%$

3. Equity to total Assets Equity / Asset $>=02 \%$

4. NPLs to Loans NPLs / Loans $=<15 \%$

5. Cost to Income ratio Cost $/$ Income $=<40 \%$

6. Loans to Assets Loan / Asset $=<65 \%$

These percentages explain a bank that;

○ has capital adequacy ratio between $8 \%$ to $40 \%$,

o has more than $4 \%$ capital to assets ratio,

- has equity to assets ratio greater than $2 \%$,

$\circ$ has controlled non-performing loans (NPLs) ratio below $15 \%$ and

- has maintained liquidity by controlling loans to assets ratio below $40 \%$

May be categorized as solvent (to super sound) bank under the bank-o-meter procedure. It is very important for management to spotlight more on trying to forecast the banks that are vulnerable to financial distress in near future using bank-o-meter ratio, which is:

$$
\mathrm{S}=1.5 * \mathrm{CA}+1.2 * \mathrm{EA}+3.5 * \mathrm{CAR}+0.6 * \mathrm{NPL}+0.3 * \mathrm{CI}+04 * \mathrm{LA}
$$

Where ' $S$ ' stands for solvency

CAR stands for capital adequacy ratio

CA stands for capital assets ratio

EA stands for equity to assets

NPL stands for non- performing loans to loans

CI stands for cost to income

LA stands for loans to assets 
And $50<\mathbf{S}<70$. All banks having an 'S' value greater than 70 are solvent and termed as super sound banks, while those having an 'S' value below 50 are not sol- vent. The area between 50 and 70 is defined as gray area because of the susceptibility to error classification.

\section{Data analysis and Interpretation}

Table 1: Bank-o-meter model Assessment and result of 2019: Conventional Banks (Source: Author's Calculation).

\begin{tabular}{|c|c|c|c|c|c|c|c|c|}
\hline \multicolumn{9}{|c|}{$\mathrm{S}=1.5 * \mathrm{CA}+1.2 * \mathrm{EA}+3.5 * \mathrm{CAR}+0.6 * \mathrm{NPL}+0.3 * \mathrm{CI}+0.4 * \mathrm{LA}$} \\
\hline Variables & CAR & CA & EA & NPL & CI & LA & \multirow{2}{*}{$\begin{array}{c}\text { S- Score Max } \\
\mathbf{7 0 \%} \& \text { Min } 50 \%\end{array}$} & \multirow[t]{2}{*}{ Rank } \\
\hline Criteria & $40 \% \leq \mathrm{CAR} \geq 8 \%$ & $\mathrm{CA} \geq 4 \%$ & $\mathbf{E A} \geq \mathbf{2} \%$ & NPL $\leq 15 \%$ & $\mathrm{CI} \leq \mathbf{4 0 \%}$ & LA $\leq 65 \%$ & & \\
\hline \multicolumn{9}{|l|}{ CBs } \\
\hline DBBL & 15.5 & 9.528 & 7.030 & 4.4 & 58.2 & 65.642 & 123.335 & 4 \\
\hline BRAC & 16.16 & 11.625 & 11.030 & 3.99 & 53 & 71.991 & 134.324 & 1 \\
\hline Bank Asia & 17.93 & 12.085 & 6.994 & 4.61 & 42 & 64.245 & 130.340 & 3 \\
\hline South East & 11.52 & 8.547 & 7.222 & 4.87 & 37.58 & 70.269 & 104.110 & 5 \\
\hline Prime & 17.42 & 12.496 & 8.306 & 4.66 & 50.82 & 66.360 & 134.267 & 2 \\
\hline \multicolumn{7}{|c|}{ Sample Average } & 125.275 & \\
\hline \multicolumn{7}{|c|}{ Classification } & \multicolumn{2}{|c|}{ Super Sound } \\
\hline
\end{tabular}

According to Bank-o-meter model, all conventional banks are the super sound of their financial health in 2019. Brac Bank Ltd. secured the top position with the ' $\mathrm{S}$ ' score of 134.324 in 2019 which is highest score among them. Southeast bank is at the bottom of the list with the least ' $S$ ' score of 104.110 in view of financial condition in 2019. The sample average ' $S$ ' score of conventional banks is 125.275 .

Table 2: Bank-o-meter model Assessment and result of 2019: Islamic Banks (Source: Author's Calculation).

\begin{tabular}{|c|c|c|c|c|c|c|c|c|}
\hline \multicolumn{9}{|c|}{$\mathrm{S}=1.5 * \mathrm{CA}+1.2 * \mathrm{EA}+3.5 * \mathrm{CAR}+0.6 * \mathrm{NPL}+0.3 * \mathrm{CI}+0.4 * \mathrm{LA}$} \\
\hline Variables & CAR & CA & EA & NPL & CI & LA & \multirow{2}{*}{$\begin{array}{c}\text { S- Score Max 70\% } \\
\text { \& Min 50\% }\end{array}$} & \multirow[t]{2}{*}{ Rank } \\
\hline Criteria & $40 \% \leq \mathrm{CAR} \geq 8 \%$ & $\mathrm{CA} \geq 4 \%$ & EA $\geq 2 \%$ & NPL $\leq 15 \%$ & $\mathrm{CI} \leq 40 \%$ & $\mathrm{LA} \leq 65 \%$ & & \\
\hline \multicolumn{9}{|l|}{ IBs } \\
\hline IBBL & 12.95 & 6.928 & 5.138 & 3.82 & 49.26 & 78.758 & 110.455 & 4 \\
\hline EXIM & 12.55 & 9.432 & 6.741 & 4.22 & 46.83 & 79.571 & 114.572 & 3 \\
\hline FSIBL & 11.41 & 6.174 & 3.520 & 4.94 & 51.6 & 82.982 & 105.058 & 5 \\
\hline SIBL & 13.78 & 8.086 & 5.005 & 6.63 & 48 & 76.587 & 115.379 & 2 \\
\hline SJIBL & 16.02 & 11.002 & 6.203 & 4.91 & 44.17 & 74.139 & 125.869 & 1 \\
\hline \multicolumn{7}{|c|}{ Sample Average } & 114.267 & \\
\hline \multicolumn{7}{|c|}{ Classification } & \multicolumn{2}{|l|}{ Super Sound } \\
\hline
\end{tabular}

Bank-o-meter model analysis of Islamic banks shows that all the Islamic banks are super sound in terms of financial soundness in 2019. Among all Islamic banks, SJIBL held the top position with the highest ' $S$ ' score of 125.869 in 2019. Contrarily, FSIBL is in the lowest position with the least ' $S$ ' score of 105.058. The sample average ' $\mathrm{S}$ ' score of all Islamic banks is 114 . 267 according Bank o meter model in 2019.

Bank-o-meter model Assessment and result for the year from 2010 to 2019.

\begin{tabular}{|c|c|c|c|c|c|c|c|c|c|c|c|c|c|}
\hline \multicolumn{10}{|c|}{ C $=\mathbf{1 . 5}$ CA+1.2* EA +3.5 * CAR+0.6*NPL+0.3*CI+0.4*LA } \\
\hline $\begin{array}{c}\text { Bank } \\
\text { Name }\end{array}$ & $\mathbf{2 0 1 9}$ & $\mathbf{2 0 1 8}$ & $\mathbf{2 0 1 7}$ & $\mathbf{2 0 1 6}$ & $\mathbf{2 0 1 5}$ & $\mathbf{2 0 1 4}$ & $\mathbf{2 0 1 3}$ & $\mathbf{2 0 1 2}$ & $\mathbf{2 0 1 1}$ & $\mathbf{2 0 1 0}$ & Mean & Status & Rank \\
\hline DBBL & 123.33 & 125.02 & 115.73 & 114.75 & 113.99 & 113.08 & 113.03 & 103.65 & 102.41 & 96.039 & 112.10 & $\begin{array}{c}\text { Super } \\
\text { Sound }\end{array}$ & 6 \\
\hline BRAC & 134.32 & 135.41 & 114.70 & 112.72 & 114.22 & 118.66 & 104.92 & 102.78 & 109.26 & 113.44 & 116.04 & $\begin{array}{c}\text { Super } \\
\text { Sound }\end{array}$ & 2 \\
\hline
\end{tabular}




\begin{tabular}{|c|c|c|c|c|c|c|c|c|c|c|c|c|c|}
\hline $\begin{array}{l}\text { Bank } \\
\text { Asia }\end{array}$ & 130.33 & 122.19 & 121.14 & 109.56 & 108.45 & 106.19 & 103.59 & 112.06 & 121.49 & 90.164 & 112.52 & $\begin{array}{l}\text { Super } \\
\text { Sound }\end{array}$ & 5 \\
\hline $\begin{array}{c}\text { South } \\
\text { East }\end{array}$ & 104.10 & 109.41 & 103.70 & 110.32 & 106.93 & 108.93 & 100.89 & 104.00 & 109.75 & 115.54 & 107.36 & $\begin{array}{l}\text { Super } \\
\text { Sound }\end{array}$ & 9 \\
\hline Prime & 134.26 & 138.34 & 125.04 & 116.37 & 115.61 & 114.20 & 110.76 & 111.64 & 112.56 & 116.80 & 119.56 & $\begin{array}{l}\text { Super } \\
\text { Sound }\end{array}$ & 1 \\
\hline IBBL & 110.45 & 108.41 & 105.48 & 104.15 & 104.83 & 109.23 & 116.78 & 114.18 & 113.13 & 106.48 & 109.31 & $\begin{array}{l}\text { Super } \\
\text { Sound }\end{array}$ & 7 \\
\hline EXIM & 114.57 & 110.56 & 115.52 & 117.43 & 114.51 & 113.34 & 118.99 & 107.67 & 113.33 & 107.93 & 113.39 & $\begin{array}{l}\text { Super } \\
\text { Sound }\end{array}$ & 4 \\
\hline FSIBL & 105.05 & 99.750 & 104.08 & 96.586 & 97.163 & 103.70 & 94.433 & 95.608 & 91.405 & 96.632 & 98.443 & $\begin{array}{l}\text { Super } \\
\text { Sound }\end{array}$ & 10 \\
\hline SIBL & 115.37 & 118.61 & 106.06 & 106.11 & 110.26 & 105.10 & 109.46 & 104.23 & 114.22 & 95.17 & 108.46 & $\begin{array}{l}\text { Super } \\
\text { Sound }\end{array}$ & 8 \\
\hline SJIBL & 125.8 & 122.27 & 112.71 & 109.81 & 120.65 & 121.12 & 116.91 & 103.74 & 103.38 & 100.81 & 113.73 & $\begin{array}{l}\text { Super } \\
\text { Sound }\end{array}$ & 3 \\
\hline
\end{tabular}

This Table shows 10 years average Bank-o-meter scores of all banks in Bangladesh. This result shows that all conventional as well as Islamic banks under the study are super sound during the study period from 2010 to 2019. Among all banks Prime bank ltd. have the highest average ' $S$ ' score of 119.564 with top posi- tion. Brac bank ltd. and SJIBL secured $2^{\text {nd }}$ and $3^{\text {rd }}$ position with average ' $S$ ' score of 116.048 and 113.729 respectively. FSIBL is in the last position with the lowest average ' $S$ ' score of 98.4431 in terms of financial health. Comparison between conventional and Islamic banks according to Bank-o-meter model given bellow:

\section{This study developed the following hypothesis}

Ho: There is no difference in financial soundness between conventional banks and Islamic banks according to Bank o meter model.

\begin{tabular}{|c|c|c|c|c|c|}
\hline \multicolumn{2}{|c|}{ Group Statistics } \\
\hline \multirow{2}{*}{ S-Score } & Conventional Banks & $\mathrm{N}$ & Mean & Std. Deviation & Std. Error Mean \\
\cline { 2 - 6 } & Islamic Banks & 50 & 113.5206 & 9.9906857 & 1.4128963 \\
\hline
\end{tabular}

The mean S-score of Conventional and Islamic banks are 113.5206 and 108.6688 with standard deviation 9.99068 and 7.99970 respectively. This means both categories of banks are financially super sound accor- ding to bank o meter model in view of financial performance but conventional banks under the study are comparatively better than Islamic banks.

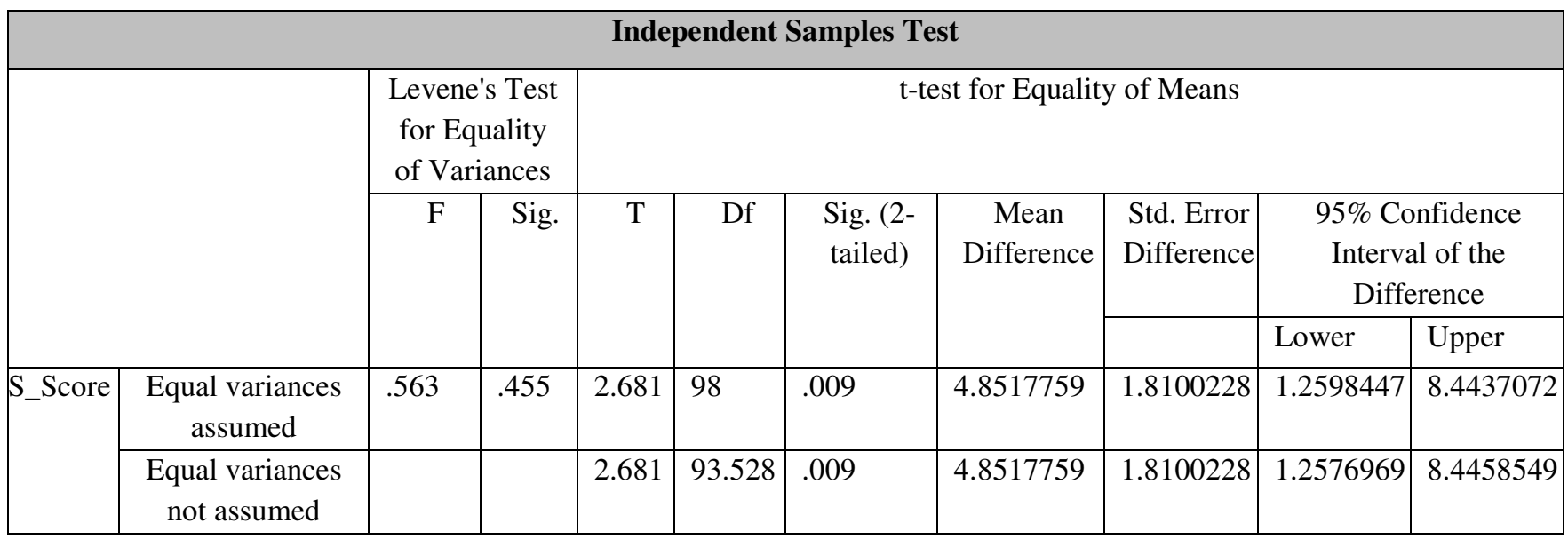


Independent Sample Test shows that the p-value of Levene's Test for equality of variance is greater than $5 \%(.455>.05)$. So, null hypothesis of equality of variance is not rejected. The p-value of the t-test for equality of means is less than $5 \%(.009>.05)$. Therefore, we reject the null hypothesis that there is no significant difference financial soundness between conventional banks and Islamic banks according to bank o meter. Thus, this study concluded that financial soundness of conventional bank is better than that of Islamic banks and it is statistically significant.

\section{CONCLUSION:}

According to bank-o-meter model, this study shows that all-conventional and Islamic banks are super sound from 2010 to 2019. Among all banks, Prime bank ltd. have the highest average ' $S$ ' score of 119.564 and secured the top position. Brac bank ltd. and Shah Jalal Islami Bank Ltd. secured 2nd and 3rd position with average ' $S$ ' scores of 116.048 and 113.729 respectively. FSIBL is in the last position with the lowest average ' $S$ ' score of 98.4431. The independent-sample $\mathrm{t}$-test of s scores of bank -o-meter model reveals that the financial soundness measured by the bank- ometer model is significantly better for conventional banks than Islamic banks as the mean s scores for conventional banks is significantly higher than Islamic banks. The mean s score is 113.52 for conventional banks and 108.66 for Islamic banks. Based on Bank-ometer, since, all the banks are super sound in terms of their financial performance. The findings of this study suggest that all the banks should maintain their consistency in financial soundness. As Islamic banks are financially less sound compared to their counterparts so, management of Islamic banks should give more emphasis on maintaining sound management and ensuring adequate liquidity.

\section{ACKNOWLEDGEMENT:}

First, my utmost gratitude goes to Almighty Allah for giving me strength, capability, and ideas to accomplish this research with His blessings. I would like to sincerely show my appreciation to my supervisor Prof. Dr. A.S.M Kumrruzaman, Dept of Finance, Rajshahi University, Rajshahi, for his unfailing support, encouragement, and kindly guidance during the completion of the paper.

UniversePG I www.universepg.com

\section{CONFLICTS OF INTEREST:}

The authors declare that there are no conflicts of interest to publish it.

\section{REFERENCES:}

1) Aktar MS. (2021). The impacts of service quality on client satisfaction: an empirical study on private commercial banks in Bangladesh, Can. J. Bus. Inf. Stud., 3(5), 80-90. https://doi.org/10.34104/cjbis.021.080090

2) Annual Report of Bank Asia Ltd. from 2010 to 2019 (Sources: websites and DSE).

3) Annual Report of Brac Bank Ltd. from 2010 to 2019 (Sources: websites and DSE).

4) Annual Report of Dutch Bangla Bank Ltd. from 2010 to 2019 (Sources: websites and DSE).

5) Annual Report of EXIM Bank Ltd. from 2010 to 2019 (Sources: websites and DSE).

6) Annual Report of First Security Islami Bank Ltd. from 2010 to 2019 (Sources: websites).

7) Annual Report of Islamic Bank Bangladesh Ltd. from 2010 to 2019 (Sources: websites and DSE).

8) Annual Report of Prime Bank Ltd. from 2010 to 2019 (Sources: websites and DSE).

9) Annual Report of Prime Bank Ltd. from 2010 to 2019 (Sources: websites and DSE).

10) Annual Report of Shahjalal Islami Bank Ltd. from 2010 to 2019 (Sources: websites and DSE)

11) Annual Report of Social Islami Ltd. from 2010 to 2019 (Sources: websites and DSE).

12) Annual Report of Southeast Bank Ltd. from 2010 to 2019 (Sources: websites and DSE).

13) Aslam Mahmud, (2020). "Bank-specific and Macroeconomic Determinants of Profitability: Evidence from Conventional Private Commercial Banks Listed on Dhaka Stock Exchange," International Journal of Science and Business, IJSAB International, 4(10), pages 99-107. https://ijsab.com/wp-content/uploads/603.pdf

14) Fayed, M. E. (2013). Comparative Performance Study of Conventional and Islamic Banking in Egypt. Journal of Applied Finance \& Banking , 3(2), 1-14.

https://www.scienpress.com/Upload/JAFB/Vol\%2 03_2_1.pdf

15) Hanif, M., Tariq, M., Tahir, A., \& Wajeeh-ulMomeneen, (2012). Comparative Performance 
Study of Conventional and Islamic Banking in Pakistan. International Research Journal of Finance and Economics 83, 62-72.

16) Khalid MS, Hans A, Arefin MS, and Hossain MR. (2021). Assessment of the heterogeneity influencing the superior of non-banking finance company for assisting consumer durable loans, Can. J. Bus. Inf. Stud., 3(1), 14-21. https://doi.org/10.34104/cjbis.021.014021

17) Khan, M.K., and Usman. A., (2012). Evaluating the Financial Performance of Islamic and Conventional Banks of Pakistan: A Comparative Analysis. International Journal of Business and Social Science, 3(7), 253-257.

www.ijbssnet.com

18) Makkar, Anita and Singh, Shveta, (2012), Evaluating the Financia Soundness of Indian Commercial Banks: An Application of Bank-o-meter. National Conference on Emerging Cha-llenges for Sustainable Business. ISBN - 978-93-8158346-3. pp. 118-132.

19) Rahman, M. Z. (2017). Financial Soundness Evaluation of Selected Commercial Banks in Bangladesh: An Application of Bankometer Model. Research Journal of Finance and Accounting, 8(2), 63-70.
https://www.iiste.org/Journals/index.php/RJFA/arti cle/view/35047

20) Safiullah, M. (2010). Superiority of Conventional Banks \& Islamic Banks of Bang-ladesh: A Comparative Study. International Journal of Economics and Finance, 2(3), 199-207.

21) Shar, A. H., Shah, D. M., \& Jamali, D. H., (2010). Performance Evaluation of Banking Sector in Pakistan: An Application of Bankometer. International Journal of Business and Management, 5(8), 113-118.

www.ccsenet.org/ijbm

22) Tabash, M. I., Yahya, A. T., \& Akhtar, A., (2017). Financial Performance Comparison of Islamic and conventional banks in the United Arab Emirates (UAE). 1st International Conference on Advances in Business, Management and Law, (2017), (pp. 477-494). Dubai: University of DUBAI - DUBAI Business School ICABML Conference Committee. https://doi.org/10.30585/icabml-cp.v1i1.39

23) Toby AJ, (2006). Banking system soundness; theory and policy. Pearl Publishers.

www.bb.org.bd

Citation: Rana S., and Kamruzzaman ASM. (2021). A comparison of financial soundness of conventional and Islamic commercial banks in Bangladesh: a bank-o-meter model approach, Int. J. Manag. Account. 3(6), 130136. https://doi.org/10.34104/ijma.021.01300136 @ @ 